\title{
Effects of Nitrogen, Phosphorus, and Potassium Rates and Fertilizer Sources on Yield and Leaf Nutrient Status of Short-day Onions
}

\author{
George E. Boyhan ${ }^{1}$ \\ Department of Horticulture, University of Georgia, East Georgia Extension \\ Center, P.O. Box 8112, GSU, Statesboro, GA 30460
}

\author{
Reid L. Torrance \\ Tattnall County Cooperative Extension Service, P.O. Box 580, Reidsville, \\ GA 30453
}

\section{Randy Hill \\ Vidalia Onion and Vegetable Research Center, 8163 Highway 178, Lyons, GA 30436}

Additional index words. spring onions, nonstorage onions, Allium cepa, tissue sampling, macronutrients, soil testing

\begin{abstract}
This is a compilation of several studies that were performed to address specific grower concerns or questions about onion fertilization, to assess onion fertility, to make adjustments in soil test recommendations, and to test specific fertilizers for clients covering the 1999-2000 to 2004-2005 seasons. The synthesis of these studies was to evaluate levels of nitrogen $(\mathrm{N})$, phosphorus $(\mathrm{P})$, and potassium $(\mathrm{K})$ fertilizers and their effect on yield, graded yield, and leaf tissue nutrient status in short-day onions over 6 years. In addition, various fertilizers were evaluated for their effect on these parameters. There was a significant increasing quadratic effect on yield from increasing $\mathbf{N}$ fertilizer from 0 to $336 \mathrm{~kg} \cdot \mathrm{ha}^{-1}$ with an $R^{2}$ of 0.926 . Maximum calculated yield was at $263 \mathrm{~kg} \cdot \mathrm{ha}^{-1}$ $\mathbf{N}$ fertilizer; however, the yield at this rate did not differ, based on a Fisher's least significant difference $(P \leq 0.05)$, from our current recommendations of 140 to $168 \mathrm{~kg} \cdot \mathrm{ha}^{-1}$ N. Jumbo ( $7.6 \mathrm{~cm}$ or greater) yield performed in a similar fashion. Phosphorus fertilizer rates from 0 to $147 \mathrm{~kg} \cdot \mathrm{ha}^{-1}$ had no effect on total yield, but did affect jumbo yields, which decreased linearly with an $R^{2}$ of 0.322 . Evaluations of $P$ fertilizer in the 2001-2002 and 2002-2003 seasons only, when the exact same $P$ fertilizer rates were used, showed a decreasing quadratic effect for jumbo yields with the lowest jumbo yields at $83 \mathrm{~kg} \cdot \mathrm{ha}^{-1}$ $P$ fertilizer and jumbo yields increasing with 115 and $147 \mathrm{~kg} \cdot \mathrm{ha}^{-1} P$ fertilizer rates. Potassium fertilizer rates from 0 to $177 \mathrm{~kg} \cdot \mathrm{ha}^{-1}$ had a quadratic affect on total yield, with the highest yield of $52,361 \mathrm{~kg} \cdot \mathrm{ha}^{-1}$ with $84 \mathrm{~kg} \cdot \mathrm{ha}^{-1} \mathrm{~K}$ fertilizer rate. As would be expected, $N$ and $P$ fertilizer rates affected leaf tissue $N$ and $P$ levels, respectively. In addition, $\mathbf{N}$ fertilizer rates affected leaf tissue calcium (Ca) and sulfur levels. Potassium fertilizer rates had a significant linear effect on leaf tissue $K 3$ of 6 years. In addition, $K$ fertilizer rates had a significant effect on leaf tissue $\mathrm{P}$ levels. Several fertilizers, including $\mathrm{Ca}\left(\mathrm{NO}_{3}\right)_{2}$ and $\mathrm{NH}_{4} \mathrm{NO}_{3}$, along with complete fertilizers and liquid fertilizers, were used as part of a complete fertilizer program and showed no differences for total yield or jumbo yield 4 of 5 years of evaluation when applied to supply the same amount of $N$ fertilizer. Based on the results of this study, soil test $P$ and $K$ recommendations for onions in Georgia have been cut $25 \%$ to $50 \%$ across the range of soil test levels.
\end{abstract}

A wide variety of experiments on onion fertility have been conducted worldwide on various soils, interaction with microorganisms, fertilizer source, and with numerous treatment levels and varieties (Gamiely et al., 1991; Sharma et al., 2003; Singh et al., 2002). Nitrogen (N) rates from 125 to $150 \mathrm{~kg} \cdot \mathrm{ha}^{-1}$ have been reported in several studies as being

\footnotetext{
Received for publication 5 Nov. 2006. Accepted for publication $23 \mathrm{Feb} .2007$.

${ }^{1}$ To whom reprint requests should be addressed; e-mail gboyhan@uga.edu
}

adequate for onion growth (Sharma et al., 2003; Singh and Singh, 2000). There have been reports, however, of $\mathrm{N}$ rates as high as $200 \mathrm{~kg} \cdot \mathrm{ha}^{-1}$ resulting in significant yield increases over lower rates (Al-Moshileh, 2001).

Fertilizer N source has also been investigated in several studies. In one such study, the fresh and dry weight were greater with $\mathrm{NO}_{3}{ }^{-}$as the $\mathrm{N}$ source compared with $\mathrm{NH}_{4}{ }^{+}$ or urea (Inal et al., 2001). Ammonium phosphate fertilizer applied early as a starter fertilizer improved early growth and final yields compared with broadcast $\mathrm{NH}_{4} \mathrm{NO}_{3}$ (Stone, 2000). This contrasts with findings that additions of diammonium phosphate postseeding did not improve the quality of transplants (Boyhan et al., 2002). These differences may be the result of different cultural practices such as direct seeding versus transplanting. Onion quality has also been linked to $\mathrm{N}$ fertility. Increasing $\mathrm{N}$ levels in hydroponic production of short-day onions has resulted in increased pyruvate, which is an indicator of pungency (Coolong and Randle, 2003).

Phosphorus $(\mathrm{P})$ requirements and utilization in onions has also been extensively studied. Phosphorus has been recommended at rates of 33 to $80 \mathrm{~kg} \cdot \mathrm{ha}^{-1}$ (Sharma et al., 2003; Singh and Singh, 2000). Phosphorus application has not been shown to affect onion yield in all cases. In one study, rates up to $160 \mathrm{~kg} \cdot \mathrm{ha}^{-1}$ had no effect on total or marketable yield (Al-Moshileh, 2001). By contrast, optimum growth and yield were obtained with $\mathrm{P}$ application of $22 \mathrm{~kg} \cdot \mathrm{ha}^{-1}$, but even higher levels gave a response with variety Pusa White Flat, which responded with optimum growth and yield at $33 \mathrm{~kg} \cdot \mathrm{ha}^{-1}$ (Jha et al., 2000). In a study in India in 1990 1991, it was shown that $P$ rates of 40 and $80 \mathrm{~kg} \cdot \mathrm{ha}^{-1}$ increased vegetative growth characteristics (plant height, leaf number), but did not affect onion yield (Singh and Singh, 1999). In addition, evaluations of $P$ rates up to $98.2 \mathrm{~kg} \cdot \mathrm{ha}^{-1}$ showed no effect on onions (Rodríguez et al., 1999).

In a comprehensive study of the effect of potassium (K) on onion growth, it was shown that yield increased up to $100 \mathrm{~kg} \cdot \mathrm{ha}^{-1}$ application rate (Singh and Verma, 2001). In addition, this study indicated that sulfate of potash $\left(\mathrm{K}_{2} \mathrm{SO}_{4}\right)$ increased yield better than muriate of potash $(\mathrm{KCl})$ and that split applications $(3 \times)$ also had a positive effect on yield. By contrast, there was no effect noted from $\mathrm{K}$ in a study on onions with rates of 0 or $150 \mathrm{~kg} \cdot \mathrm{ha}^{-1}$ (Al-Moshileh, 2001). A study in China reported increased yield with $\mathrm{K}$ applications up to $240 \mathrm{~kg} \cdot \mathrm{ha}^{-1}$, but sugar content was lower than when lower K rates were used (Guo XiSheng et al., 1999). A study in Egypt with $\mathrm{K}$ rates from 0 to $184 \mathrm{~kg} \cdot \mathrm{ha}^{-1}$ indicated that on sandy soils, $\mathrm{K}$ increased onion yield up to $123 \mathrm{~kg} \cdot \mathrm{ha}^{-1}$, but on clay soil, there was an increase over the untreated control but no difference between $\mathrm{K}$ rates (Abo-Zeid and Farghali, 1996).

This study was not planned as a cohesive evaluation of $\mathrm{N}, \mathrm{P}$, and $\mathrm{K}$, but rather reflects ongoing and changing efforts to understand onion fertilizer requirements while meeting specific extension needs of growers and others as well as evaluate new fertilizer products being offered to the industry. Initially, the first experiment was to validate current recommendations (1999-2000 season). This was expanded to evaluate $\mathrm{N}$ and $\mathrm{K}$ over a wider range of application rates because these were considered most limiting to production. Cultivated soils in Georgia generally test high for $\mathrm{P}$, yet onion growers use a considerable amount of P-containing fertilizers. Phosphorus fertilizer rates were then added to evaluate onion response to this element. Over the course of these experiments, various new 
fertilizer products, primarily slow-release fertilizers, were also evaluated.

The objective of this study was to compile and synthesize six years of onion fertility experiments to reevaluate $\mathrm{N}, \mathrm{P}$, and $\mathrm{K}$ fertilization effect on yield and tissue nutrient status in the Vidalia growing area of southeast Georgia with the ultimate goal of reevaluating soil test recommendations. In addition, several commercially available fertilizer sources were evaluated for their effect on yield and leaf nutrient status.

\section{Materials and Methods}

All experiments were conducted at the Vidalia Onion and Vegetable Research Center (VOVRC) in Lyons, Ga. (lat. $32^{\circ} 11^{\prime} \mathrm{N}$, long. $82^{\circ} 17^{\prime} \mathrm{W}$ ) on a Tifton soil (fine-loamy, siliceous, thermic Plinthic Paleudults). This soil is typical of soils found throughout the onion growing region of southeast Georgia. Land used for these experiments did not have onions planted the previous season. Soil $\mathrm{pH}$ was adjusted to 6.0 to 6.5 with dolomitic lime as needed according to University of Georgia soil test recommendations for onions
(Boyhan et al., 2001). All varieties used were midseason, short-day onions on the official list of approved varieties (Boyhan et al., 2005; State of Georgia, 2005). All transplants used were grown at the VOVRC according to University of Georgia Cooperative Extension Service recommendations (Boyhan et al., 2001). These experiments were conducted on beds formed with $1.8 \mathrm{~m}$ center to center between adjacent beds. Each bed was planted with four rows of transplants with a $30.5-\mathrm{cm}$ between-row and 14-cm in-row spacing. Each experiment was arranged in a randomized complete-block design of four replications with the experimental unit consisting of a plot, $6.1 \mathrm{~m}$ long of planted bed, which included $\approx 175$ plants. All treatments were broadcast-applied by hand. Liquid fertilizer treatments were mixed with $7.6 \mathrm{~L}$ of water and broadcast-applied with a watering can. All treatment applications were personally supervised by the senior author. University of Georgia Cooperative Extension Service recommendations were followed for disease, insect, and weed control as well as irrigation timing and amount (Boyhan et al., 2001). Plants were sprinkler-irrigated from an over- head portable pipe system. Table 1 lists fertilizer material, fertilizer element used to determine rate, and rate of application for experiments from the 1999-2000 through 2004-2005 seasons. Aside from the different treatment rates, the $\mathrm{N}, \mathrm{P}, \mathrm{K}$, and sulfur (S) rates applied followed University of Georgia soil test recommendations for that season unless noted otherwise. Leaf tissue samples were analyzed with protocols of Isaac and Johnson (1985).

The entire experimental unit was harvested for yield data. Harvested onions were pulled on the date of harvest and allowed to field cure for $2 \mathrm{~d}$ before removing tops and roots. Onions were then heat-cured for $24 \mathrm{~h}$ at $35{ }^{\circ} \mathrm{C}$ before grading. Onions were graded with a Haines grader (Avoca, N.Y.) into jumbos $(7.6 \mathrm{~cm}$ or greater) and mediums (5.1 or greater $\mathrm{cm}$ and less than $7.6 \mathrm{~cm}$ ). Culls, including undersized, damaged, diseased, or misshapen bulbs, were removed before sizing.

Total yield, graded yield, and leaf tissue $\mathrm{N}, \mathrm{P}, \mathrm{K}$, calcium $(\mathrm{Ca})$, and $\mathrm{S}$ were compiled and analyzed with Microsoft Excel 11.1.1 (Microsoft Corp., Redmond, Wash.) and

Table 1. Fertilizer source material, fertilizer element used to determine rate, and rate of fertilizer element application. ${ }^{\mathrm{z}}$

\begin{tabular}{|c|c|c|c|c|c|c|c|}
\hline \multirow[b]{2}{*}{ Fertilizer material } & \multicolumn{6}{|c|}{ Rate $\left(\mathrm{kg} \cdot \mathrm{ha}^{-1}\right)$} & \multirow[b]{2}{*}{ 2004-2005 } \\
\hline & Element & $1999-2000^{y}$ & $2000-2001$ & $2001-2002$ & $2002-2003$ & $2003-2004$ & \\
\hline$\overline{-}$ & $\mathrm{N}$ & & 0 & 0 & & 0 & 0 \\
\hline $\mathrm{Ca}\left(\mathrm{NO}_{3}\right)_{2}$ & $\mathrm{~N}$ & & 84 & 84 & & 28 & 28 \\
\hline $\mathrm{Ca}\left(\mathrm{NO}_{3}\right)_{2}$ & $\mathrm{~N}$ & 90 & 112 & 112 & & 56 & 56 \\
\hline $\mathrm{Ca}\left(\mathrm{NO}_{3}\right)_{2}$ & $\mathrm{~N}$ & 118 & 140 & 140 & & 84 & 84 \\
\hline $\mathrm{Ca}\left(\mathrm{NO}_{3}\right)_{2}$ & $\mathrm{~N}$ & 146 & 168 & 168 & & 112 & 112 \\
\hline $\mathrm{Ca}\left(\mathrm{NO}_{3}\right)_{2}$ & $\mathrm{~N}$ & & 196 & 196 & & 140 & 140 \\
\hline $\mathrm{Ca}\left(\mathrm{NO}_{3}\right)_{2}$ & $\mathrm{~N}$ & & & & & 168 & 168 \\
\hline $\mathrm{Ca}\left(\mathrm{NO}_{3}\right)_{2}$ & $\mathrm{~N}$ & & & & & 224 & 224 \\
\hline $\mathrm{Ca}\left(\mathrm{NO}_{3}\right)_{2}$ & $\mathrm{~N}$ & & & & & 336 & 336 \\
\hline - & $\mathrm{P}$ & & & 0 & 0 & & \\
\hline $\mathrm{Ca}\left(\mathrm{H}_{2} \mathrm{PO}_{4}\right)_{2} \cdot \mathrm{xH}_{2} \mathrm{O}+\mathrm{CaSO}_{4}$ & $\mathrm{P}$ & & & 20 & 20 & & \\
\hline $\mathrm{Ca}\left(\mathrm{H}_{2} \mathrm{PO}_{4}\right)_{2} \cdot \mathrm{xH}_{2} \mathrm{O}+\mathrm{CaSO}_{4}$ & $\mathrm{P}$ & & & 51 & 51 & & \\
\hline $\mathrm{Ca}\left(\mathrm{H}_{2} \mathrm{PO}_{4}\right)_{2} \cdot \mathrm{xH}_{2} \mathrm{O}+\mathrm{CaSO}_{4}$ & $\mathrm{P}$ & & & 83 & 83 & & \\
\hline $\mathrm{Ca}\left(\mathrm{H}_{2} \mathrm{PO}_{4}\right)_{2} \cdot \mathrm{xH}_{2} \mathrm{O}+\mathrm{CaSO}_{4}$ & $\mathrm{P}$ & & & 115 & 115 & & \\
\hline $\mathrm{Ca}\left(\mathrm{H}_{2} \mathrm{PO}_{4}\right)_{2} \cdot \mathrm{xH}_{2} \mathrm{O}+\mathrm{CaSO}_{4}$ & $\mathrm{P}$ & & & 147 & 147 & & \\
\hline - & $\mathrm{K}$ & & 0 & 0 & 0 & & \\
\hline $\mathrm{KCl}$ & $\mathrm{K}$ & 9 & 65 & 65 & 65 & & \\
\hline $\mathrm{KCl}$ & $\mathrm{K}$ & 37 & 93 & 93 & 93 & & \\
\hline $\mathrm{KCl}$ & $\mathrm{K}$ & 65 & 121 & & & & \\
\hline $\mathrm{KCl}$ & $\mathrm{K}$ & & 149 & 149 & 149 & & \\
\hline $\mathrm{KCl}$ & $\mathrm{K}$ & & 177 & 177 & 177 & & \\
\hline $\mathrm{NH}_{4} \mathrm{NO}_{3}$ & $\mathrm{~N}$ & 146 & 168 & 168 & & & \\
\hline$\left(\mathrm{NH}_{4}\right)_{2} \mathrm{H}_{2} \mathrm{PO}_{4}$ & $\mathrm{~N}$ & & & & $84^{\mathrm{x}}$ & & \\
\hline$\left(\mathrm{NH}_{4}\right)_{2} \mathrm{H}_{2} \mathrm{PO}_{4}$ & $\mathrm{~N}$ & & & & $112^{\mathrm{x}}$ & & \\
\hline$\left(\mathrm{NH}_{4}\right)_{2} \mathrm{H}_{2} \mathrm{PO}_{4}$ & $\mathrm{~N}$ & 146 & $168^{\mathrm{x}}$ & $168^{\mathrm{x}}$ & $168^{\mathrm{x}}$ & & \\
\hline Fortified peat & $\mathrm{N}$ & 146 & 168 & 168 & & & \\
\hline $14-0-10-8 \mathrm{~S}$ and $28-0-0$ & $\mathrm{~N}$ & & $174^{\mathrm{w}}$ & $168^{w}$ & $168^{w}$ & & \\
\hline $19-3.5-15.8-4.9 \mathrm{~S}$ & $\mathrm{~N}$ & & $168^{w}$ & $168^{w}$ & $168^{w}$ & & \\
\hline 5-4.4-12.4-9S, $\left(\mathrm{NH}_{4}\right)_{2} \mathrm{H}_{2} \mathrm{PO}_{4}, \mathrm{Ca}\left(\mathrm{NO}_{3}\right)_{2}$ & $\mathrm{~N}$ & & & & & $168^{w}$ & $168^{w}$ \\
\hline $10-4.4-8.3-12 \mathrm{~S}, \mathrm{Ca}\left(\mathrm{NO}_{3}\right)_{2}$ & $\mathrm{~N}$ & & & & & $168^{w}$ & \\
\hline $30-0-0$ & $\mathrm{~N}$ & & & & & & $118^{\mathrm{u}}$ \\
\hline $30-0-0$ & $\mathrm{~N}$ & & & & & $168^{v}$ & $168^{\mathrm{u}}$ \\
\hline $10-4.4-8.3-12 \mathrm{~S}$ & $\mathrm{~N}$ & & & & & & $168^{\mathrm{tw}}$ \\
\hline
\end{tabular}

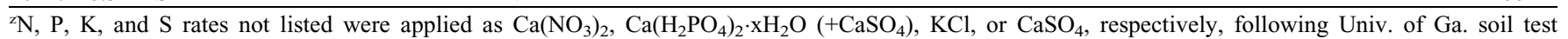
recommendations.

y $5-4.4-12.4-9 \mathrm{~S}$ was preplant incorporated to all treatments at $448 \mathrm{~kg} \cdot \mathrm{ha}^{-1}$ and no additional $\mathrm{P}$ was added.

${ }^{\mathrm{x}}$ No additional $\mathrm{P}$ fertilizer was applied.

wNo additional fertilizer was applied to this treatment.

vThree different treatments - all applied on 6 Jan. 2004, split-applied 6 and 26 Jan. 2004, or split-applied 6 Jan. and 24 Feb. 2004.

"Two different treatments - all applied on 24 Nov. 2004 or split-applied 24 Nov. 2004 and 16 Feb. 2005.

${ }^{\mathrm{t}}$ Two different treatments-three equal applications on 24 Nov. 2004, 12 Jan. and 16 Feb. 2005 or split-applied on 24 Nov. 2004 and 16 Feb. 2005.

$\mathrm{N}=$ nitrogen; $\mathrm{P}=$ phosphorus; $\mathrm{K}=$ potassium; $\mathrm{S}=$ sulfur; $\mathrm{Ca}=$ calcium. 
Stata 9.2 (StataCorp, College Station, Texas). The analysis of variance (ANOVA) assumed that years were a random variable. In addition, ANOVA was calculated overall treatment levels and not just treatment levels listed in Table 1. For example, soil test $\mathrm{K}$ recommendations were $112 \mathrm{~kg} \cdot \mathrm{ha}^{-1}$ for the 1999-2000 and 2000-2001 seasons; $167 \mathrm{~kg} \cdot \mathrm{ha}^{-1}$ for the 2001-2002, 2002-2003, and 2003-2004 seasons; and $84 \mathrm{~kg} \cdot \mathrm{ha}^{-1}$ for the 2004-2005 season and these were used in the analyses of $\mathrm{K}$ fertilizer treatments along with those listed in Table 1 . The same was done with $\mathrm{P}$ analyses. The treatment $\times$ year mean square was used as the error mean square for treatments (Gomez and Gomez, 1984). Fisher's protected least significant difference (LSD), when reported, was calculated at $P \leq 0.05$. Linear and quadratic equations and $\mathrm{R}^{2}$ values were calculated after computing treatment means across replications as per Gomez and Gomez (1984). Orthogonal linear and quadratic contrasts were calculated when appropriate according to a method of Grandage (1958).

1999-2000 season. In the 1999-2000 growing season, the University of Georgia soil test recommendation was to apply 168 $\mathrm{kg} \cdot \mathrm{ha}^{-1} \mathrm{~N}, 20 \mathrm{~kg} \cdot \mathrm{ha}^{-1} \mathrm{P}, 112 \mathrm{~kg} \cdot \mathrm{ha}^{-1} \mathrm{~K}$, and $67 \mathrm{~kg} \cdot \mathrm{ha}^{-1} \mathrm{~S}$, which was used as a guideline to plan this experiment, which included nine treatments (Table 1). Fertilizer $(5 \mathrm{~N}-4.4 \mathrm{P}-$ $12.5 \mathrm{~K}-9 \mathrm{~S})$ was applied preplant and incorporated at a rate of $448 \mathrm{~kg} \cdot \mathrm{ha}^{-1}$ to all plots, which resulted in $22 \mathrm{~N}-20 \mathrm{P}-56 \mathrm{~K}-40 \mathrm{~S}$ $\mathrm{kg} \cdot \mathrm{ha}^{-1}$. Eight-week-old 'Granex 33' bareroot transplants, with $50 \%$ of their tops removed, were transplanted on 9 Dec. 1999 to these plots. All fertilizer treatments were split-applied with one-half applied on 27 Jan. 2000 and one-half applied on 28 Feb. 2000.

The first, second, and third treatments were different $\mathrm{N}$ fertilizer rates applied as $\mathrm{Ca}\left(\mathrm{NO}_{3}\right)_{2}$, which resulted in 112,140 , or $168 \mathrm{~kg} \cdot \mathrm{ha}^{-1} \mathrm{~N}$. The next three treatments consisted of $\mathrm{KCl}$ applied for a total of 65,93 , or $121 \mathrm{~kg} \cdot \mathrm{ha}^{-1} \mathrm{~K}$, respectively. The next two treatments used $\mathrm{NH}_{4} \mathrm{NO}_{3}$ or $\left(\mathrm{NH}_{4}\right)_{2} \mathrm{H}_{2} \mathrm{PO}_{4}$ as $\mathrm{N}$ sources, respectively. Finally, the last treatment consisted of a fortified peat $(10 \% \mathrm{~N})$ (Organic Products, Ludowici, Ga.), which was a locally mined (Long Co., Ludowici, Ga.) material that had been blended with urea in a proprietary process to yield a product with $10 \% \mathrm{~N}$.

Leaf tissue samples, which consisted of five to six of the most recently mature leaves, were collected from each plot on 10 Apr. 2000 and analyzed for $\mathrm{N}, \mathrm{P}, \mathrm{K}$, and $\mathrm{Ca}$. Onions were harvested and total yield recorded on 9 May 2000.

2000-2001 season. In the 2000-2001 season, there were 17 treatments, which were planted with variety Sweet Melissa (Table 1). The plants were transplanted on 30 Nov. 2000. The soil test for onions this year recommended $168 \mathrm{~kg} \cdot \mathrm{ha}^{-1}, 20 \mathrm{~kg} \cdot \mathrm{ha}^{-1}$, and $112 \mathrm{~kg} \cdot \mathrm{ha}^{-1}$ of $\mathrm{N}, \mathrm{P}$, and $\mathrm{K}$, respectively, and $67 \mathrm{~kg} \cdot \mathrm{ha}^{-1} \mathrm{~S}$. All of the recommended $\mathrm{P}$ was applied on 6 Dec. 2000 unless a complete fertilizer source was used. $\mathrm{S}$ fertilizer was split-applied with half applied on 6 Dec. 2000 and half applied on 5 Feb. 2001 unless S was part of the fertilizer formulation. Applications of $\mathrm{N}$ and $\mathrm{K}$ were applied in thirds on 6 Dec. 2000, 5 Feb. 2001, and 2 Mar. 2001.

Treatments 1 through 6 applied $\mathrm{N}$ at rates of $0,84,112,140,168$, or $196 \mathrm{~kg} \cdot \mathrm{ha}^{-1}$. The next six treatments applied $\mathrm{K}$ at rates of 0 , $65,93,121,149$, or $177 \mathrm{~kg} \cdot \mathrm{ha}^{-1}$. The next two treatments applied $168 \mathrm{~kg} \cdot \mathrm{ha}^{-1} \mathrm{~N}$ as either $\mathrm{NH}_{4} \mathrm{NO}_{3}$ or $\left(\mathrm{NH}_{4}\right)_{2} \mathrm{H}_{2} \mathrm{PO}_{4}$. The next applied fortified peat as the $\mathrm{N}$ source. The last two treatments consisted of complete fertilizers, one consisting of slow-release liquid $14 \mathrm{~N}$ 0P-10K-8S (Regal Chemical Co., Alpharetta, Ga.) applied at a rate of $327 \mathrm{~L} \cdot \mathrm{ha}^{-1}$ on 6 Dec. 2000 and 5 Feb. 2001. In addition, $140 \mathrm{~L} \cdot \mathrm{ha}^{-1}$ of slow-release 28-0-0 (Regal Chemical Co.) was applied on 2 Mar. 2001. The next treatment consisted of a polymer coated 19N-3.5P-15.8K-4.9S (Helena Chemical Co., Collierville, Tenn.) band applied on 30 Nov. 2000 just before transplanting below each row at a rate of $168 \mathrm{~kg} \cdot \mathrm{ha}^{-1} \mathrm{~N}$.

Leaf samples were collected on 27 Mar. 2001 for analyses of N, P, K, Ca, and S. Onions were harvested 3 May 2001 and total or field yield was recorded for each experimental unit. In addition, onions were cured and then graded into size classes of jumbos, which were $7.6 \mathrm{~cm}$ or greater in diameter and mediums, which were $5.1 \mathrm{~cm}$ or greater and less than $7.6 \mathrm{~cm}$ in diameter.

2001-2002 season. In the 2001-2002 season, there were 22 treatments (Table 1). Variety Sweet Melissa was transplanted on 5 Dec. 2001. The soil test this year recommended 168, 20, 167, and $67 \mathrm{~kg} \cdot \mathrm{ha}^{-1}$ of N, P, K, and S, respectively. All of the P was applied in the first application on 6 Dec. 2001. S was split-applied in equal amounts on the first and second application dates of 6 Dec. 2001, and 29 Jan. 2002. N and K applications were split into thirds and applied on 6 Dec. 2001, 29 Jan. 2002, and 25 Feb. 2002.

The first six treatments applied $\mathrm{Ca}\left(\mathrm{NO}_{3}\right)_{2}$ at rates of $0,84,112,140,168$, or $196 \mathrm{~kg} \cdot \mathrm{ha}^{-1}$ $\mathrm{N}$. The next six treatments were $\mathrm{Ca}\left(\mathrm{H}_{2} \mathrm{PO}_{4}\right)_{2}$ $\cdot \mathrm{xH}_{2} \mathrm{O}+\mathrm{CaSO}_{4}(0 \mathrm{~N}-8.7 \mathrm{P}-0 \mathrm{~K})$ at rates of 0 , $20,51,83,115$, or $147 \mathrm{~kg} \cdot \mathrm{ha}^{-1} \mathrm{P}$ split into three applications, which were applied on 6 Dec. 2001, 29 Jan. and 25 Feb. 2002. Potassium was applied as $\mathrm{KCl}$ at rates of 0,65 , 93, 149, or $177 \mathrm{~kg} \cdot \mathrm{ha}^{-1}$. $\mathrm{NH}_{4} \mathrm{NO}_{3}$ applied at $168 \mathrm{~kg} \cdot \mathrm{ha}^{-1}$ was also an $\mathrm{N}$ source treatment as was $\left(\mathrm{NH}_{4}\right)_{2} \mathrm{H}_{2} \mathrm{PO}_{4}$. In addition, fortified peat $(10 \% \mathrm{~N})$ applied to deliver $168 \mathrm{~kg} \cdot \mathrm{ha}^{-1} \mathrm{~N}$ was also a treatment. The next treatment was liquid $14 \mathrm{~N}-0 \mathrm{P}-10 \mathrm{~K}-8 \mathrm{~S}$ applied at a rate of $439 \mathrm{~L} \cdot \mathrm{ha}^{-1}$ on 6 Dec. 2001 and 25 Feb. 2002. Finally, a polymer-coated $19 \mathrm{~N}-3.5 \mathrm{P}-15.8 \mathrm{~K}-$ 4.9S was broadcast-applied on 6 Dec. 2001 at a rate of $168 \mathrm{~kg} \cdot \mathrm{ha}^{-1} \mathrm{~N}$.

Leaf tissue samples were collected on 18 Mar. 2002 for analyses. Onions were harvested 8 May 2002 and total yield was recorded for each experimental unit. In addition, onions were graded into size classes of jumbos and mediums.

2002-2003 season. In the 2002-2003 season, there were 16 treatments (Table 1).
Variety Nirvana was transplanted on 4 Dec. 2002. The soil test this year recommended $168,20,167$, and $67 \mathrm{~kg} \cdot \mathrm{ha}^{-1}$ of $\mathrm{N}, \mathrm{P}, \mathrm{K}$, and $\mathrm{S}$, respectively. All of the $\mathrm{P}$ was applied in the first application on 3 Jan. 2003 unless indicated otherwise. S was split-applied in equal amounts on the first and second application dates of 3 Jan. and 6 Feb. 2003. N and K applications were split into thirds and applied on 3 Jan., 6 Feb., and 4 Mar. 2003.

Treatments 1 through 6 applied $\mathrm{Ca}\left(\mathrm{H}_{2} \mathrm{PO}_{4}\right)_{2}$ $\cdot \mathrm{xH}_{2} \mathrm{O}+\mathrm{CaSO}_{4}(0 \mathrm{~N}-8.7 \mathrm{P}-0 \mathrm{~K})$ at rates of $0,20,51,83,115$, or $147 \mathrm{~kg} \cdot \mathrm{ha}^{-1} \mathrm{P}$ split into three applications, which were applied on 3 Jan., 6 Feb., and 4 Mar. 2003. These treatments received $168 \mathrm{~kg} \cdot \mathrm{ha}^{-1} \mathrm{~N}$ as $\mathrm{Ca}\left(\mathrm{NO}_{3}\right)_{2}$. The next five treatments applied $\mathrm{KCl}$ at rates of $0,65,93,149$, or $177 \mathrm{~kg} \cdot \mathrm{ha}^{-1} \mathrm{~K}$. $\left(\mathrm{NH}_{4}\right)_{2} \mathrm{H}_{2} \mathrm{PO}_{4}$ at rates of 84,112 , or $168 \mathrm{~kg} \cdot \mathrm{ha}^{-1} \mathrm{~N}$ were also treatments. Liquid $14 \mathrm{~N}-0 \mathrm{P}-10 \mathrm{~K}-8 \mathrm{~S}$ at a rate of $439 \mathrm{~L} \cdot \mathrm{ha}^{-1}$ on 3 Jan. and 4 Mar. 2003 was also a treatment. Finally, a polymer-coated $19 \mathrm{~N}-3.5 \mathrm{P}-15.8 \mathrm{~K}-$ 4.9S broadcast-applied on 3 Jan. 2003 at a rate of $168 \mathrm{~kg} \cdot \mathrm{ha}^{-1} \mathrm{~N}$ was included.

Leaf samples were collected on 12 Mar. 2003 for analyses. Onions were harvested 30 Apr. 2003 and total yield was recorded for each experimental unit. In addition, onions were graded into size classes of jumbos and mediums.

2003-2004 season. In the 2003-2004 season, there were 14 treatments in the experiment (Table 1). Variety Sweet Vidalia was transplanted on 25 Nov. 2003. The soil test recommendations called for 168, 20, 167, and $67 \mathrm{~kg} \cdot \mathrm{ha}^{-1}$ of $\mathrm{N}, \mathrm{P}, \mathrm{K}$, and $\mathrm{S}$, respectively, which was used to determine nontreatment nutrient rates. The first nine treatments applied rates of $\mathrm{N}$ at $0,28,56,84,112,140$, 168,224 , or $336 \mathrm{~kg} \cdot \mathrm{ha}^{-1}$, which were splitapplied in three applications on 6 and 26 Jan. and $24 \mathrm{Feb}$. 2004. The next treatment applied $448 \mathrm{~kg} \cdot \mathrm{ha}^{-1}$ of $5 \mathrm{~N}-4.4 \mathrm{P}-12.4 \mathrm{~K}-9 \mathrm{~S}$ and 168 $\mathrm{kg} \cdot \mathrm{ha}^{-1}$ of $\left(\mathrm{NH}_{4}\right)_{2} \mathrm{H}_{2} \mathrm{PO}_{4}$, which was applied on 8 Dec. 2003. This was followed by a second application of $448 \mathrm{~kg} \cdot \mathrm{ha}^{-1}$ of $5 \mathrm{~N}-$ 4.4P-12.4K-9S on 6 Jan. 2004. On 26 Jan. $2004,224 \mathrm{~kg} \cdot \mathrm{ha}^{-1}$ of $5 \mathrm{~N}-4.4 \mathrm{P}-12.4 \mathrm{~K}-9 \mathrm{~S}$ was applied and finally on 24 Feb. 2004, 504 $\mathrm{kg} \cdot \mathrm{ha}^{-1}$ of $\mathrm{Ca}\left(\mathrm{NO}_{3}\right)_{2}$ was applied. The next treatment applied $448 \mathrm{~kg} \cdot \mathrm{ha}^{-1}$ of $10 \mathrm{~N}-4.4 \mathrm{P}$ $8.3 \mathrm{~K}-12 \mathrm{~S}$ on $8 \mathrm{Dec}$. 2003. This was followed by $448 \mathrm{~kg} \cdot \mathrm{ha}^{-1} 10 \mathrm{~N}-4.4 \mathrm{P}-8.3 \mathrm{~K}-12 \mathrm{~S}$ applied on 6 Jan. 2004. Finally, $252 \mathrm{~kg} \cdot \mathrm{ha}^{-1}$ of $\mathrm{Ca}\left(\mathrm{NO}_{3}\right)_{2}$ was applied on 26 Jan. and 24 Feb. 2004. The next three treatments had $452 \mathrm{~L} \cdot \mathrm{ha}^{-1}$ of slow-release liquid $30 \mathrm{~N}-0 \mathrm{P}-$ 0K (Georgia-Pacific Resins, Atlanta, Ga.) applied. One treatment applied all the material on 6 Jan. 2004. The next treatment was split-applied with half applied on 6 Jan. and half applied on 26 Jan. 2004. Finally, 30N$0 \mathrm{P}-0 \mathrm{~K}$ was split-applied with half applied on 6 Jan. and half applied on 24 Feb. 2004.

Leaf samples were collected on 22 Mar. 2004 for analyses. Onions were harvested 4 May 2004 and total yield was recorded. In addition, onions were graded into size classes of jumbos and mediums as described previously. 
2004-2005 season. In the 2004-2005 season, there were 16 treatments in the experiment (Table 1). Variety Sweet Vidalia was transplanted on 18 Nov. 2004. The soil test recommendations called for 168, 20, 84, and $67 \mathrm{~kg} \cdot \mathrm{ha}^{-1}$ of $\mathrm{N}, \mathrm{P}, \mathrm{K}$, and $\mathrm{S}$, respectively, which was used to determine nontreatment fertilizer applications. The first nine treatments applied rates of $\mathrm{N}$ at $0,28,56,84,112$, $140,168,224$, or $336 \mathrm{~kg} \cdot \mathrm{ha}^{-1}$ split into three equal applications of $\mathrm{Ca}\left(\mathrm{NO}_{3}\right)_{2}$, which were made on 24 Nov. 2004, and 12 Jan. and 16 Feb. 2005. Treatment 10 applied $448 \mathrm{~kg} \cdot \mathrm{ha}^{-1}$ of $5 \mathrm{~N}-4.4 \mathrm{P}-12.4 \mathrm{~K}-9 \mathrm{~S}$ and $168 \mathrm{~kg} \cdot \mathrm{ha}^{-1}$ of $\left(\mathrm{NH}_{4}\right)_{2} \mathrm{H}_{2} \mathrm{PO}_{4}$ on 24 Nov. 2004. This was followed by a second application of 448 $\mathrm{kg} \cdot \mathrm{ha}^{-1}$ of $5 \mathrm{~N}-4.4 \mathrm{P}-12.4 \mathrm{~K}-9 \mathrm{~S}$ on $12 \mathrm{Jan}$. 2005. Finally, on $16 \mathrm{Feb}$. 2005, $448 \mathrm{~kg} \cdot \mathrm{ha}^{-1}$ of $\mathrm{Ca}\left(\mathrm{NO}_{3}\right)_{2}$ was applied. The next treatment used liquid $30 \mathrm{~N}-0 \mathrm{P}-0 \mathrm{~K}$ applied at a rate of $316 \mathrm{~L} \cdot \mathrm{ha}^{-1}$, which was all applied on $24 \mathrm{Nov}$. 2004. In addition, this same product was used as a treatment, but was split-applied with half (158 L.ha ${ }^{-1}$ ) applied on 24 Nov. 2004 and half $\left(158 \mathrm{~L} \cdot \mathrm{ha}^{-1}\right)$ applied on 16 Feb. 2005. Liquid $30 \mathrm{~N}-0 \mathrm{P}-0 \mathrm{~K}$ was also used for the next treatment and was applied at $452 \mathrm{~L} \cdot \mathrm{ha}^{-1}$, which was all applied on 24 Nov. 2004. The next treatment used this same product, but was split-applied with half $\left(226 \mathrm{~L} \cdot \mathrm{ha}^{-1}\right)$ applied on 24 Nov. 2004 and half $\left(226 \mathrm{~L} \cdot \mathrm{ha}^{-1}\right)$ applied on $16 \mathrm{Feb}$. 2005. Finally, the last two treatments supplied $168 \mathrm{~kg} \cdot \mathrm{ha}^{-1}$ applied as $10 \mathrm{~N}-4.4 \mathrm{P}-8.3 \mathrm{~K}-12 \mathrm{~S}$ either in three equal applications on 24 Nov. 2004 and 12 Jan. and 16 Feb. 2005 or two equal applications on 24 Nov. 2004 and 16 Feb. 2005.

Leaves were collected on $28 \mathrm{Feb} .2005$ for analyses of $\mathrm{N}, \mathrm{P}, \mathrm{K}, \mathrm{Ca}$, and $\mathrm{S}$ as described previously. Onions were harvested 20 May 2005 and total yield was recorded for each experimental unit. In addition, onions were graded into size classes of jumbos and mediums.

\section{Results and Discussion}

Nitrogen fertilizer rates. There was a significant treatment $\times$ year interaction for total yield and jumbos with increasing $\mathrm{N}$ fertilizer rates (Fig. 1), but an examination of the individual years indicated a similar quadratic effect in all cases except for total yield differences in the 1999-2000 and 2000-2001 seasons when there were no statistically significant differences. Medium yield also had a quadratic effect when individual years are examined except for the 2000-2001 season.

The quadratic equation for total yield was $y=-0.4863 x^{2}+256.2 x+16769$. Solving the derivative of this equation for zero results in a maximum $\mathrm{N}$ rate of $263 \mathrm{~kg} \cdot \mathrm{ha}^{-1}$, which is significantly higher than our current recommendation. If, however, a Fisher's protected LSD is calculated, the maximum calculated yield does not differ from yields at 140 to $168 \mathrm{~kg} \cdot \mathrm{ha}^{-1} \mathrm{~N}$ fertilizer, which is our current recommendation.

Solving the derivative of the jumbo quadratic equation $\left(\mathrm{y}=-0.2562 \mathrm{x}^{2}+145.25 \mathrm{x}+\right.$ 5535) for 0 results in a maximum yield with

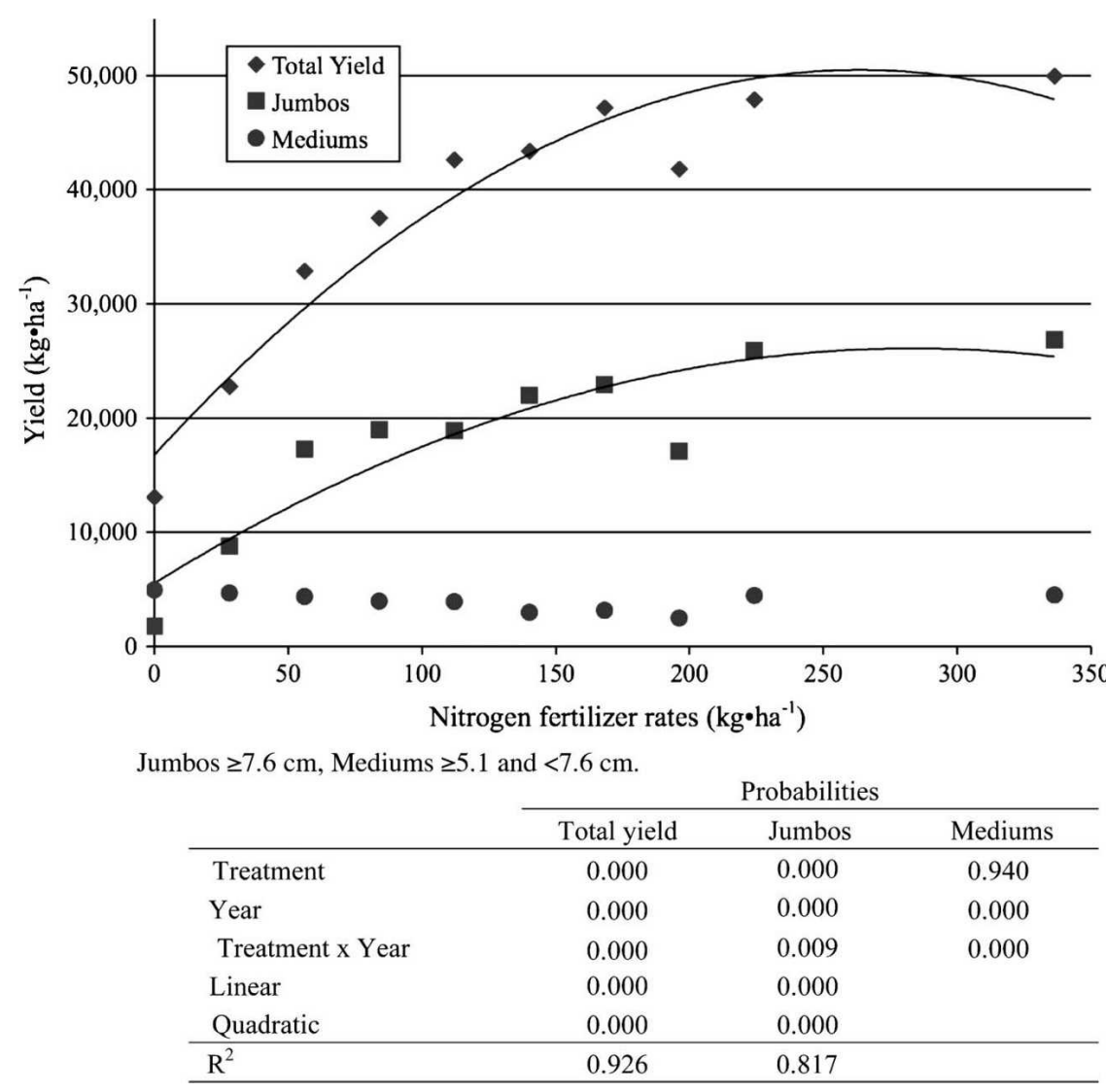

Fig. 1. Yield response to nitrogen fertilizer rates with quadratic trendlines, effect probabilities, and $\mathrm{R}^{2}$ values.

$283 \mathrm{~kg} \cdot \mathrm{ha}^{-1} \mathrm{~N}$, but with Fisher's LSD, there is no difference between this calculated maximum jumbo yield and jumbo yields for 140 to $168 \mathrm{~kg} \cdot \mathrm{ha}^{-1} \mathrm{~N}$ fertilizer rate.

Medium yields in individual years with significant quadratic effects showed a slight decrease in medium yields with increasing $\mathrm{N}$ fertilizer followed by a slight increase at higher rates. This tracks fairly well with jumbo yields as would be expected. An increase in onion size into the jumbo size class would result in a decrease in the number in the medium size class.

These results are intriguing that based on the derivative equations total and jumbo yields are at a maximum near or above 250 $\mathrm{kg} \cdot \mathrm{ha}^{-1} \mathrm{~N}$. This suggests, at least, that higher $\mathrm{N}$ fertilizer rates may be helpful in increasing yield, but it should be noted that the very highest $\mathrm{N}$ rates were only applied in 2 years of the study and there were only two very high rates, 224 and $336 \mathrm{~kg} \cdot \mathrm{ha}^{-1}$. This apparent ambiguity in the amount of $\mathrm{N}$ fertilizer is also part of the literature with rates reported from 125 to $200 \mathrm{~kg} \cdot \mathrm{ha}^{-1}$ for optimum onion production (Al-Moshileh, 2001; Sharma et al., 2003). Further study with more rates above our current maximum recommendation of $168 \mathrm{~kg} \cdot \mathrm{ha}^{-1}$ would help clarify this.

Leaf tissue $\mathrm{N}$ had a significant quadratic effect that ranged from $18.2 \mathrm{mg} \cdot \mathrm{g}^{-1}$ to $36.3 \mathrm{mg} \cdot \mathrm{g}^{-1}$ with $\mathrm{N}$ fertilizer rates of 0 to $336 \mathrm{~kg} \cdot \mathrm{ha}^{-1}$ (Fig. 2). There were no differences in leaf tissue $\mathrm{P}$ based on $\mathrm{N}$ fertilizer rates. Leaf tissue $\mathrm{K}$ had a $\mathrm{N}$ fertilizer $\times$ year interaction that is difficult to interpret with a significant effect in 2 of 5 years. In the 2000-2001 season, there was a significant linear increase in leaf tissue $\mathrm{K}$ with increasing $\mathrm{N}$ fertilizer and in the 2004-2005 season, there was a significant increasing quadratic effect that peaked with $140 \mathrm{~kg} \cdot \mathrm{ha}^{-1} \mathrm{~N}$ fertilizer. There was a significant quadratic affect on leaf $\mathrm{Ca}$ levels based on $\mathrm{N}$ fertilizer rates. Leaf tissue Ca levels ranged from a low of 8.5 $\mathrm{mg} \cdot \mathrm{g}^{-1}$ for $\mathrm{N}$ fertilizer rates of 84 and 196 $\mathrm{kg} \cdot \mathrm{ha}^{-1}$ to $14.0 \mathrm{mg} \cdot \mathrm{g}^{-1}$ for an $\mathrm{N}$ fertilizer rate of $336 \mathrm{~kg} \cdot \mathrm{ha}^{-1}$. Leaf tissue S levels showed a quadratic effect based on $\mathrm{N}$ fertilizer rates, which ranged from 3.7 to $7.0 \mathrm{mg} \cdot \mathrm{g}^{-1}$.

Leaf tissue sampling was not done on the same day each year. The earliest sampling date occurred in 2005 when samples were collected on $28 \mathrm{Feb}$. and the latest sampling date was in 2000 on 10 Apr., which represents a 41-d difference. This might have been a problem, but there were no $\mathrm{N}$ fertilizer $\times$ year interactions for any of the leaf tissue elements tested, except for $K$, suggesting that either the precision of leaf tissue testing may not be that exact in determining crop nutrient status for any particular date over this time frame or that leaf tissue nutrient status in not that fungible from one date to the next within this time frame.

Leaf tissue $\mathrm{N}$ levels generally did not differ much over the range of $\mathrm{N}$ fertilizer except for the $0 \mathrm{~kg} \cdot \mathrm{ha}^{-1} \mathrm{~N}$ treatment. There was only a $20 \%$ difference from the highest to the lowest leaf tissue $\mathrm{N}$ level from the highest to the lowest $\mathrm{N}$ fertilizer level excluding the $0 \mathrm{~kg} \cdot \mathrm{ha}^{-1} \mathrm{~N}$ rate. The $\mathrm{N}$ fertilizer rate with the lowest leaf tissue $\mathrm{N}$ rate was $84 \mathrm{~kg} \cdot \mathrm{ha}^{-1} \mathrm{~N}$, 


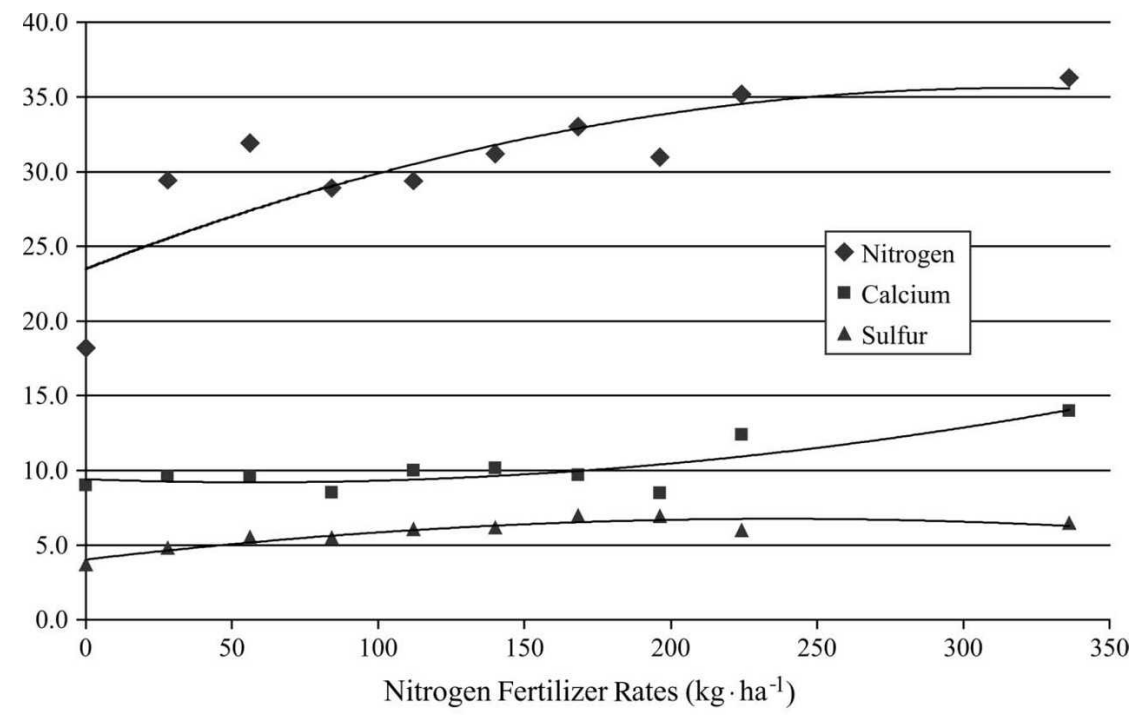

\begin{tabular}{lccccc} 
& \multicolumn{5}{c}{ Probabilities } \\
\cline { 2 - 5 } & Nitrogen & Phosphorus & Potassium & Calcium & Sulfur \\
\hline Treatment & 0.000 & 0.256 & 0.232 & 0.012 & 0.000 \\
Year & 0.000 & 0.002 & 0.000 & 0.000 & 0.000 \\
Treatment $\times$ Year & 0.665 & 0.960 & 0.000 & 0.197 & 0.156 \\
Linear & 0.000 & & & 0.000 & 0.000 \\
Quadratic & 0.042 & & 0.036 & 0.000 \\
\hline $\mathrm{R}^{2}$ & 0.663 & & 0.727 & 0.866 \\
\hline
\end{tabular}

Fig. 2. Leaf tissue nitrogen, calcium, and sulfur response to nitrogen fertilizer rates with quadratic trendlines, effect probabilities, and $\mathrm{R}^{2}$ values.

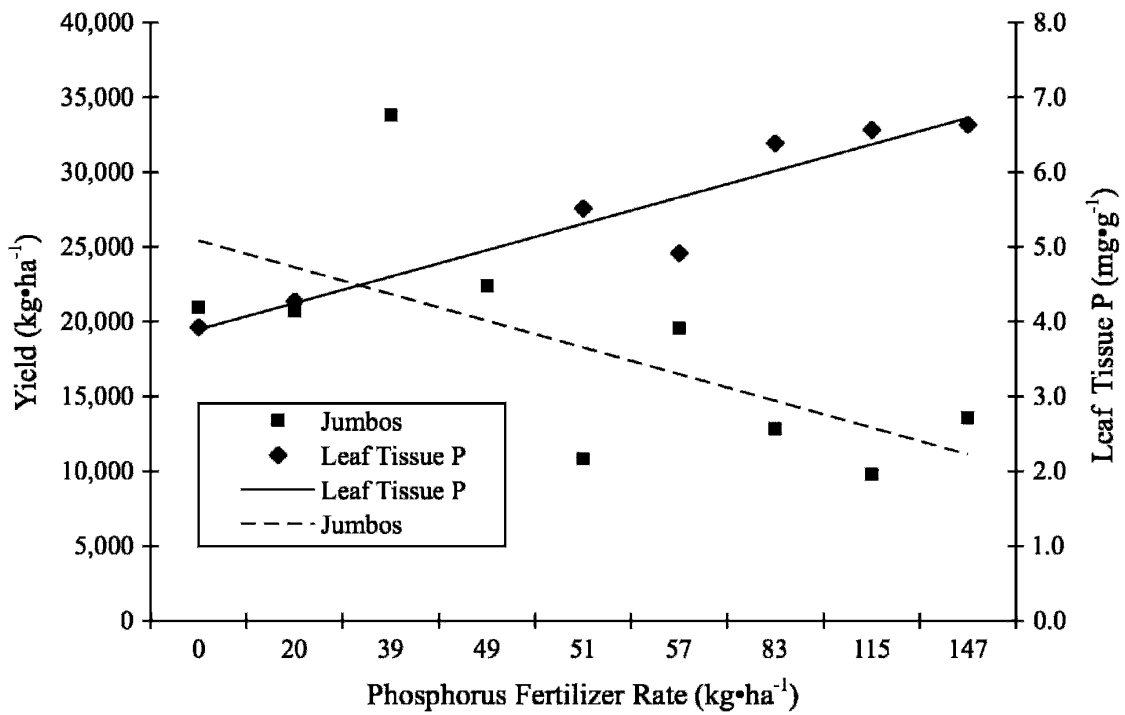

Jumbos $\geq 7.6 \mathrm{~cm}$

\begin{tabular}{lcccccccc} 
& \multicolumn{10}{c}{ Probabilities } \\
\cline { 2 - 9 } & $\begin{array}{l}\text { Total } \\
\text { yield }\end{array}$ & Jumbos & Mediums & $\mathrm{N}$ & $\mathrm{P}$ & $\mathrm{K}$ & $\mathrm{Ca}$ & $\mathrm{S}$ \\
\hline Treatment & 0.069 & 0.001 & 0.118 & 0.098 & 0.038 & 0.434 & 0.412 & 0.201 \\
Year & 0.000 & 0.000 & 0.014 & 0.402 & 0.002 & 0.025 & 0.053 & 0.001 \\
Treatment x Year & 0.666 & 0.914 & 0.794 & 0.668 & 0.121 & 0.698 & 0.824 & 0.200 \\
Linear & & 0.000 & & & 0.000 & & & \\
Quadratic & & 0.873 & & & 0.284 & & & \\
\hline $\mathrm{R}^{2}$ & & 0.322 & \multicolumn{7}{c}{0.879} & & & \\
\hline
\end{tabular}

Fig. 3. Jumbo yield and leaf tissue phosphorus response to phosphorus fertilizer rates with linear trendlines, effect probabilities, and $\mathrm{R}^{2}$ values (2000-2005). which was $37 \%$ greater than the $0 \mathrm{~kg} \cdot \mathrm{ha}^{-1} \mathrm{~N}$ rate. This indicates, at least as measured in this study, that leaf tissue $\mathrm{N}$ is not a very good predictor of crop $\mathrm{N}$ need or yield.

Leaf tissue $\mathrm{K}$ levels had a by-year interaction with increasing $\mathrm{N}$ fertilizer. When leaf tissue $\mathrm{K}$ is examined for the individual years, only 2 years, 2001 and 2005, show significant differences. Presumably, in 2000 , there were not enough $\mathrm{N}$ fertilizer rates to indicate any differences, but this does not explain the lack of differences in 2002 and 2004; however, Coolong et al. (2004) found that onion bulb tissue $\mathrm{K}$ was unaffected by $\mathrm{N}$ fertilizer levels under hydroponic conditions. In addition, if the $0 \mathrm{~kg} \cdot \mathrm{ha}^{-1} \mathrm{~N}$ rate is excluded in 2001 and 2005 , the remaining leaf tissue $\mathrm{K}$ measurements are not different from each other. $\mathrm{N}$ fertilizer, if there is any effect, on leaf tissue $\mathrm{K}$ appears to have an initiation effect from $0 \mathrm{~kg} \cdot \mathrm{ha}^{-1}$ to $28 \mathrm{~kg} \cdot \mathrm{ha}^{-1} \mathrm{~N}$ fertilizer levels but no effect over the complete range of $\mathrm{N}$ fertilizer applied in this experiment.

Although leaf tissue $\mathrm{Ca}$ levels had a quadratic effect with increasing $\mathrm{N}$ fertilizer, in general, leaf tissue $\mathrm{Ca}$ hovered around 9 to $10 \mathrm{mg} \cdot \mathrm{g}^{-1}$ throughout the $\mathrm{N}$ fertilizer range except for the very highest $\mathrm{N}$ fertilizer rates, 224 and $336 \mathrm{~kg} \cdot \mathrm{ha}^{-1}$, in which leaf tissue $\mathrm{Ca}$ jumped to 12.4 and $14.0 \mathrm{mg} \cdot \mathrm{g}^{-1}$, respectively. These high $\mathrm{Ca}$ levels were probably an artifact of using $\mathrm{Ca}\left(\mathrm{NO}_{3}\right)_{2}$ as the $\mathrm{N}$ source, which may be a side benefit because $\mathrm{Ca}$ is known to be an important indicator of postharvest storability in many commodities, including onions (Srinivasan et al., 2002).

Excluding the two highest $\mathrm{N}$ fertilizer rates results in a significant linear increase in tissue $\mathrm{S}$ levels over the range of 0 to $196 \mathrm{~kg} \cdot \mathrm{ha}^{-1} \mathrm{~N}$. This has an $\mathrm{R}^{2}$ value of 0.918 compared with an $\mathrm{R}^{2}$ value of 0.866 for a quadratic effect over the entire $\mathrm{N}$ fertilizer range ( 0 to $\left.336 \mathrm{~kg} \cdot \mathrm{ha}^{-1}\right)$. S precursors are known to rapidly convert to pungent compounds on maceration of onion tissue (Randle and Bussard, 1993). Randle (2000) has shown that when $\mathrm{N}$ is at very low levels, the $\mathrm{S}$ precursors that will ultimately impart greater heat are at higher levels than those precursors that impart a fresh onion flavor, 1-propenyl cysteine sulfoxide versus methyl cysteine sulfoxide. In addition, we have observed that small onions (for example, from parts of the field where center-pivot irrigation does not reach) are more pungent. Leaf tissue $\mathrm{S}$ alone, then, is not enough to predict onion pungency because it occurs at relatively low levels with $0 \mathrm{~kg} \cdot \mathrm{ha}^{-1} \mathrm{~N}$ when onions are small but are generally more pungent.

Looking at the 2000-2001 and 20012002 seasons together as well as the 20032004 and 2004-2005 seasons together because each set of seasons has exactly the same $\mathrm{N}$ fertilizer rates sheds little additional light on onion response to increasing $\mathrm{N}$ fertilizer rates. In the 2000-2001 and 20012002 seasons for total yield, there was a treatment $\times$ year interaction with the 2000 2001 season having no significant response, whereas in the 2001-2002 season, there was an increasing quadratic response (data not 
shown). In addition, leaf tissue $\mathrm{Ca}$ and $\mathrm{S}$ showed no significant response to $\mathrm{N}$ fertilizer rates as they did overall years and $\mathrm{N}$ fertilizer rates. In the 2003-2004 and 2004-2005 seasons, the yield and graded yield response was the same as for all years with the exception that the treatment-by-year interaction for jumbos was no longer significant. Finally, the leaf tissue nutrients for the 20032004 and 2004-2005 seasons were the same as for the overall analysis except $\mathrm{Ca}$ was no longer significant.

Phosphorus fertilizer rates. Surprisingly, $\mathrm{P}$ fertilizer rates did not affect total or medium yields (Fig. 3). Jumbo yields had a significant downward linear effect from $\mathrm{P}$ fertilizer, but with an $R^{2}$ value of only 0.322 ; however, if the $39 \mathrm{~kg} \cdot \mathrm{ha}^{-1}$ and $51 \mathrm{~kg} \cdot \mathrm{ha}^{-1} \mathrm{P}$ fertilizer rates, which appear visually to be outliers (Gomez and Gomez, 1984), are excluded, the $\mathrm{R}^{2}$ value for a linear function has a much better fit with an $\mathrm{R}^{2}$ of 0.665 . Leaf tissue $\mathrm{N}, \mathrm{K}$, $\mathrm{Ca}$, and $\mathrm{S}$ were unaffected by $\mathrm{P}$ fertilizer rates. Leaf tissue $\mathrm{P}$ on the other hand increased linearly with increasing $P$ fertilizer rates.

A further evaluation of $P$ fertilizer effect with only the 2001-2002 and 2002-2003 data, because these two seasons had the exact same $\mathrm{P}$ fertilizer treatments, gives a somewhat different picture of the results (Fig. 4). Total yield remains unaffected, whereas jumbo and medium yields are significantly affected with jumbos having a quadratic response and mediums a linear response. Jumbo yields decrease through the 83 $\mathrm{kg} \cdot \mathrm{ha}^{-1} \mathrm{P}$ fertilizer rate and then increase with the 115 and $147 \mathrm{~kg} \cdot \mathrm{ha}^{-1} \mathrm{P}$ fertilizer rate. Medium yields have a decreasing linear response.

Total yield is the best predictor of treatment response because it is unaffected by potential bias; all the onions for a specific experimental unit are harvested and weighed, whereas both jumbos and mediums undergo a culling process in which diseased, damaged, and misshapen bulbs are removed. This step relies on the judgment of those doing the culling and may introduce some unintentional bias. It should be pointed out, however, that on examination of the data for each year, results were similar but nonsignificant. It is unclear why this occurs, but the highest rates of 115 and $147 \mathrm{~kg} \cdot \mathrm{ha}^{-1}$ were applied only in the 2001-2002 and 20022003 seasons. This may be an area for further research.

Cultivated soils in southeast Georgia routinely test high or very high for P content; therefore, soil test recommendations are low (20 $\mathrm{kg} \cdot \mathrm{ha}^{-1}$ throughout this study). Growers on the other hand generally use a considerable amount of $\mathrm{P}$ fertilizer as high as $89 \mathrm{~kg} \cdot \mathrm{ha}^{-1}$ based on a standard fertilizer program (Boyhan et al., 2001). Plots with significant amounts of $\mathrm{P}$ fertilizer, particularly $\left(\mathrm{NH}_{4}\right)_{2} \mathrm{H}_{2} \mathrm{PO}_{4}$, usually appear greener with larger tops. Beginning in the 2001-2002 season, a more extensive evaluation was undertaken of $\mathrm{P}$ fertilizer rates. Results from the 2001-2002 season showed no yield differences between different $P$ rates (data not

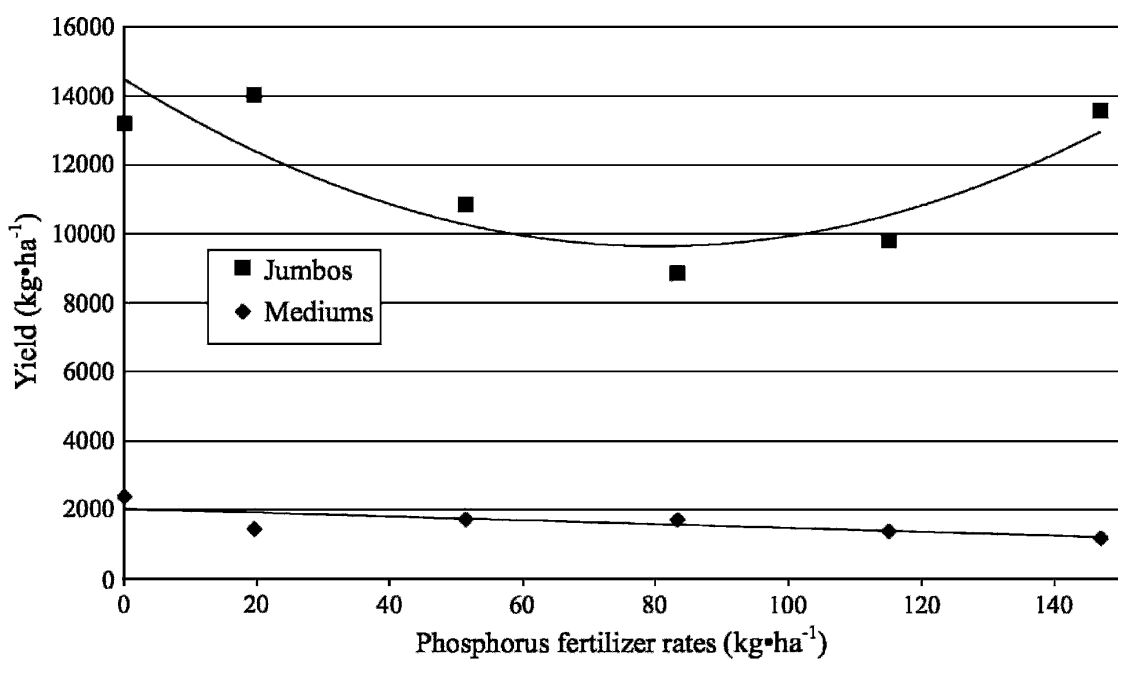

Jumbos $\geq 7.6 \mathrm{~cm}$, Mediums $\geq 5.1$ and $<7.6 \mathrm{~cm}$.

\begin{tabular}{lcccccccc} 
& \multicolumn{8}{c}{ Probabilities } \\
\cline { 2 - 9 } & $\begin{array}{l}\text { Total } \\
\text { yield }\end{array}$ & Jumbos & Mediums & $\mathrm{N}$ & $\mathrm{P}$ & $\mathrm{K}$ & $\mathrm{Ca}$ & $\mathrm{S}$ \\
\hline Treatment & 0.833 & 0.016 & 0.020 & 0.851 & 0.060 & 0.282 & 0.490 & 0.309 \\
Year & 0.000 & 0.067 & 0.364 & 0.280 & 0.009 & 0.152 & 0.604 & 0.002 \\
Treatment x Year & 0.516 & 0.961 & 0.978 & 0.531 & 0.110 & 0.917 & 0.753 & 0.071 \\
Linear & & 0.442 & 0.038 & & & & & \\
Quadratic & & 0.035 & 0.834 & & & & & \\
\hline $\mathrm{R}^{2}$ & & 0.739 & 0.575 & & & & & \\
\hline
\end{tabular}

Fig. 4. Jumbo and medium yields response to phosphorus fertilizer rates with quadratic trendline for jumbos and linear trendline for mediums, effect probabilities, and $\mathrm{R}^{2}$ values (2002-2003).

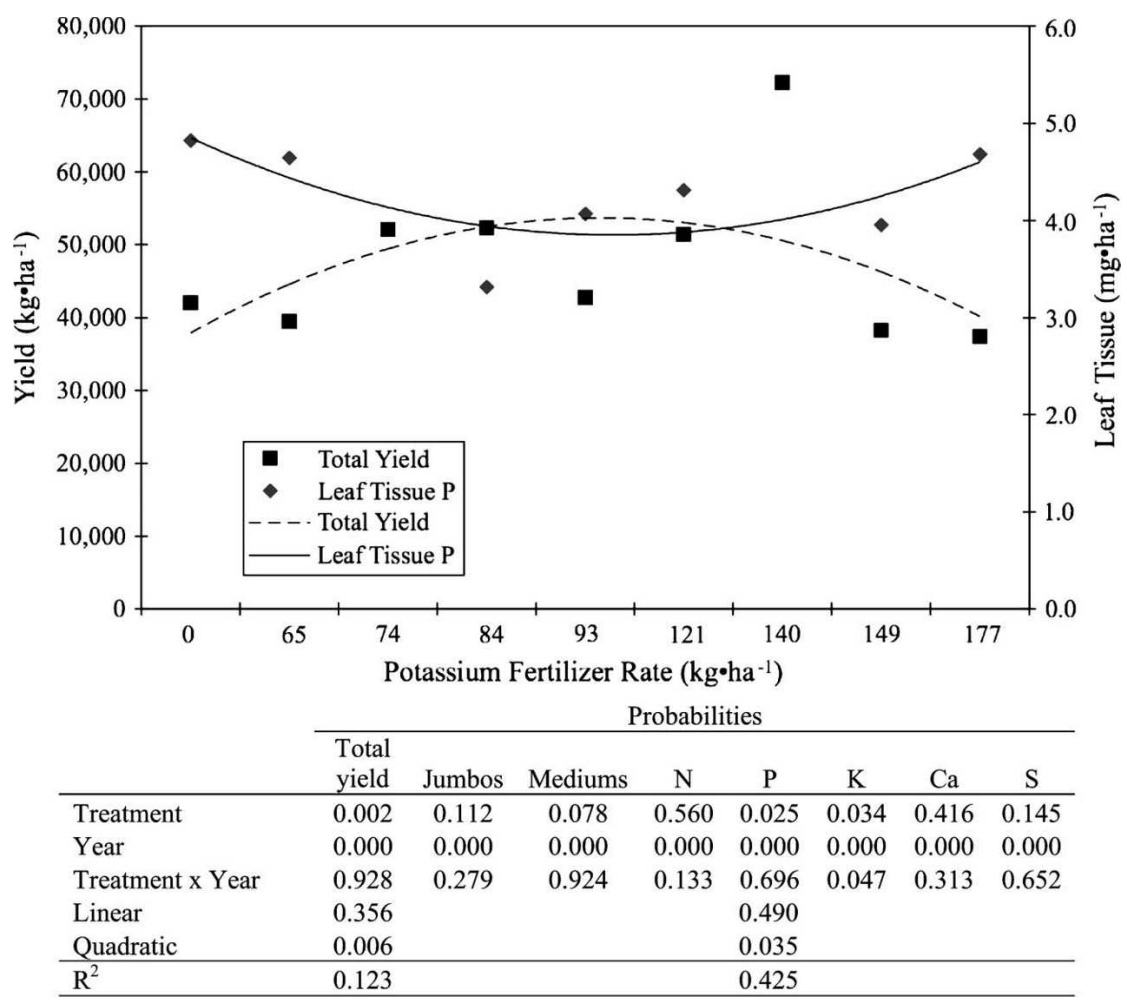

Fig. 5. Total yield and leaf tissue phosphorus response to potassium fertilizer rates with quadratic trendlines, effect probabilities, and $\mathrm{R}^{2}$ values.

shown), although the tops were greener and larger. The following season (2002-2003), treatments were included not only with different rates of $\mathrm{P}$, but with $\mathrm{NH}_{4} \mathrm{NO}_{3}$ as the $\mathrm{N}$ source assuming that the ammonium source in conjunction with $\mathrm{P}$ fertilizer may have an effect because these effects are most noticeable with $\left(\mathrm{NH}_{4}\right)_{2} \mathrm{H}_{2} \mathrm{PO}_{4}$. Again, this proved to be fruitless with no differences among $\mathrm{P}$ fertilizer rates that year (data not shown). 
Table 2. Comparison of different fertilizer effects on total yield, graded yield, and tissue nutrient levels in short-day onions.

\begin{tabular}{|c|c|c|c|c|c|c|c|c|}
\hline \multirow[b]{2}{*}{ Fertilizer source ${ }^{z}$} & \multirow[b]{2}{*}{ Total yield $\left(\mathrm{kg} \cdot \mathrm{ha}^{-1}\right)$} & \multirow[b]{2}{*}{$\operatorname{Jumbos}^{\mathrm{x}}\left(\mathrm{kg} \cdot \mathrm{ha}^{-1}\right)$} & \multirow[b]{2}{*}{$\operatorname{Mediums}^{\mathrm{x}}\left(\mathrm{kg} \cdot \mathrm{ha}^{-1}\right)$} & \multicolumn{5}{|c|}{ Leaf tissue $\left(\mathrm{mg} \cdot \mathrm{g}^{-1}\right)$} \\
\hline & & & & $\mathrm{N}$ & $\mathrm{P}$ & $\mathrm{K}$ & $\mathrm{Ca}$ & $\mathrm{S}$ \\
\hline Fortified peat, $10 \% \mathrm{~N}$ & 51,459 & 14,629 & 1531 & 29.6 & 5.0 & 32.4 & 6.9 & 8.4 \\
\hline $\mathrm{Ca}\left(\mathrm{NO}_{3}\right)_{2}$ & 43,269 & 20,278 & 2846 & 34.5 & 4.3 & 40.5 & 9.5 & 6.8 \\
\hline $\mathrm{NH}_{4} \mathrm{NO}_{3}$ & 47,173 & 16,887 & 1546 & 35.4 & 4.4 & 38.2 & 7.4 & 7.2 \\
\hline$\left(\mathrm{NH}_{4}\right)_{2} \mathrm{H}_{2} \mathrm{PO}_{4}$ & 50,082 & 14,893 & 1000 & 38.1 & 6.4 & 35.8 & 7.4 & 8.3 \\
\hline $14-0-128 \%$ S liquid ${ }^{y}$ & 38,698 & 13,272 & 2448 & 35.1 & 3.7 & 36.0 & 5.8 & 6.2 \\
\hline $19-8-19$ & 39,939 & 15,297 & 1983 & 29.9 & 4.9 & 33.2 & 5.6 & 5.1 \\
\hline $30-0-0$ liquid & 45,758 & 25,331 & 5137 & 35.7 & 3.9 & 55.2 & 12.2 & 6.9 \\
\hline \multicolumn{9}{|l|}{ Probabilities } \\
\hline Treatments & 0.085 & 0.571 & 0.151 & 0.019 & 0.002 & 0.233 & 0.007 & 0.064 \\
\hline Year & 0.000 & 0.000 & 0.000 & 0.000 & 0.000 & 0.000 & 0.000 & 0.000 \\
\hline Treatment $\times$ year & 0.608 & 0.049 & 0.096 & 0.179 & 0.003 & 0.001 & 0.116 & 0.000 \\
\hline $\operatorname{LSD}^{\mathrm{w}}$ & NS & & NS & 8.7 & & & 2.0 & \\
\hline $\mathrm{CV}^{\mathrm{v}}$ & $15 \%$ & $45 \%$ & $49 \%$ & $17 \%$ & $27 \%$ & $17 \%$ & $16 \%$ & $30 \%$ \\
\hline
\end{tabular}

${ }^{\mathrm{z}}$ Each applied to deliver $168 \mathrm{~kg} \cdot \mathrm{ha}{ }^{-1} \mathrm{~N}, \mathrm{P}, \mathrm{K}$, and S nutrients were applied as $\left.\mathrm{Ca}\left(\mathrm{H}_{2} \mathrm{PO}_{4}\right)_{2} \cdot \mathrm{xH}_{2} \mathrm{O}(+\mathrm{CaSO})_{4}\right), \mathrm{KCl}_{\text {, or CaSO }}$ unless treatment was a complete fertilizer according to Univ. of Ga. soil test recommendations.

${ }^{y}$ In 2000-2001 season additional fertilizer applied with 28-0-0 to deliver a total of $174 \mathrm{~kg} \cdot \mathrm{ha}^{-1} \mathrm{~N}$.

xumbos $7.6 \mathrm{~cm}$ or greater; mediums 5.1 or greater and less than $7.6 \mathrm{~cm}$.

${ }^{w}$ Fisher's protected least significant difference $(P \leq 0.05)$.

${ }^{\mathrm{v}}$ Coefficient of variation.

$\mathrm{N}=$ nitrogen; $\mathrm{P}=$ phosphorus; $\mathrm{K}=$ potassium; $\mathrm{Ca}=$ calcium; $\mathrm{S}=$ sulphur.

High P fertilizer may be warranted when onion tops are damaged such as during hailstorms, which are known to occur in southeast Georgia during late winter or early spring, but this may be too late in the season to have much effect, because onions are generally harvested beginning in April. In addition, there is a small market for salad onions in which immature onions are sold with leaves attached. These onions may also benefit from high $\mathrm{P}$ fertilizer in which large green tops are important.

Potassium fertilizer rates. Potassium fertilizer rates had a quadratic effect on total yields but did not affect jumbo or medium onion yields (Fig. 5). Leaf tissue N, Ca, or $\mathrm{S}$ levels were also unaffected, but leaf tissue $P$ levels were affected in a quadratic fashion. In addition, there was a $\mathrm{K}$ fertilizer $\times$ year interaction for leaf tissue $\mathrm{K}$ levels with 3 years showing an increase in leaf tissue $\mathrm{K}$ with increasing $\mathrm{K}$ fertilizer and 3 showing no effect (data not shown).

Potassium fertilizer rate appears to be only weakly associated with total yield. Although there is a quadratic effect with increasing $\mathrm{K}$ fertilizer, the $\mathrm{R}^{2}$ is only 0.123 . If the $140 \mathrm{~kg} \cdot \mathrm{ha}^{-1} \mathrm{~K}$ fertilizer rate is removed, because it appears visually to be an outlier (Gomez and Gomez, 1984), then the quadratic effect has an $\mathrm{R}^{2}$ of 0.390 . Although this is better, it is still a very low $\mathrm{R}^{2}$ value. It is unclear why leaf tissue $\mathrm{P}$ would be significantly affected by $\mathrm{K}$ fertilizer rate. The

Table 3. University of Georgia soil test ranges with old and new onion recommendations for phosphorus and potassium on the coastal plain soils using Mehlich-1 extraction. ${ }^{z}$

\begin{tabular}{|c|c|c|c|c|c|c|}
\hline \multirow[b]{2}{*}{ Test level } & \multicolumn{2}{|c|}{$\begin{array}{l}\text { Test ranges } \\
\left(\mathrm{kg} \cdot \mathrm{ha}^{-1}\right)\end{array}$} & \multicolumn{2}{|c|}{$\begin{array}{c}\text { Old onion } \\
\text { recommendations }\left(\mathrm{kg} \cdot \mathrm{ha}^{-1}\right)\end{array}$} & \multicolumn{2}{|c|}{$\begin{array}{c}\text { New onion } \\
\text { recommendations }\left(\mathrm{kg} \cdot \mathrm{ha}^{-1}\right)\end{array}$} \\
\hline & $\mathrm{P}$ & $\mathrm{K}$ & $\mathrm{P}$ & $\mathrm{K}$ & $\mathrm{P}$ & $\mathrm{K}$ \\
\hline$\overline{\text { Low }}$ & $0-34$ & $0-78$ & 118 & 223 & 59 & 112 \\
\hline Medium & $35-67$ & 79-191 & 78 & 167 & 44 & 84 \\
\hline High & $68-112$ & $192-308$ & 39 & 112 & 29 & 56 \\
\hline Very high & $112+$ & $308+$ & 20 & 56 & 15 & 28 \\
\hline Overload & 224 & 448 & & & 0 & 0 \\
\hline
\end{tabular}

${ }^{\mathrm{z}}$ Mehlich (1953).

$\mathrm{P}=$ phosphorus; $\mathrm{K}=$ potassium.

quadratic effect may be the result of a dilution effect, because as onion yield increases through the midrange of $\mathrm{K}$ fertilizer rates, there is a lower amount of $\mathrm{P}$ concentrated in the leaf tissue, which then becomes more concentrated as yield goes down again at the very highest $\mathrm{K}$ fertilizer rates.

Finally, looking only at the 2000-2001, 2001-2002, and 2002-2003 data, which all had the same rates of $\mathrm{K}$ fertilizer and excluding the $\mathrm{K}$ rate of $121 \mathrm{~kg} \cdot \mathrm{ha}^{-1}$ in the 2000 2001 season because it only occurs in this season (Table 1), there are in fact no differences for yield, graded yield, or leaf tissue analyses resulting from $\mathrm{K}$ fertilizer rates (data not shown).

Surprisingly, there was a by-year interaction with $\mathrm{K}$ fertilizer rate and leaf tissue $\mathrm{K}$ levels. In 6 years of evaluations, the leaf tissue $\mathrm{K}$ increased in a linear fashion with increasing $\mathrm{K}$ fertilizer only half the time. This appears to be in line with the overall effect of $\mathrm{K}$ in onion performance. Its weak association with increasing yield is mirrored in the weak association with leaf tissue $\mathrm{K}$ levels and increasing $\mathrm{K}$ fertilizer.

Fertilizer evaluations. Different fertilizers were also evaluated in this study (Table 2). There was no difference in total yield among the fertilizer sources tested, and although there was a fertilizer source-by-year interaction for jumbos, an examination of this data by year indicated only 1 year in which

HortScience Vol. 42(3) June 2007 there was a significant difference between fertilizers. In addition, there were no differences for medium onions among the various fertilizers. In years in which slow-release liquid $30 \mathrm{~N}-0 \mathrm{P}-0 \mathrm{~K}$ fertilizer was tested, split applications had higher total and jumbo yields compared with applying all the fertilizer in one application (data not shown).

Leaf tissue $\mathrm{N}$ at $38.1 \mathrm{mg} \cdot \mathrm{g}^{-1}$ was highest with the $\left(\mathrm{NH}_{4}\right)_{2} \mathrm{H}_{2} \mathrm{PO}_{4}$. There were differences in leaf tissue $\mathrm{Ca}$ levels based on fertilizer source with the $30 \mathrm{~N}-0 \mathrm{P}-0 \mathrm{~K}$ liquid fertilizer having the highest level compared with all other treatments.

Leaf tissue $\mathrm{P}, \mathrm{K}$, and $\mathrm{S}$ all had treatment $\times$ year interactions. Leaf tissue $P$ showed significant differences among the various fertilizer sources tested for all 5 years and, not unexpectedly, $\left(\mathrm{NH}_{4}\right)_{2} \mathrm{H}_{2} \mathrm{PO}_{4}$ had the highest leaf tissue $\mathrm{P}$ levels in years it was tested. Leaf tissue $\mathrm{K}$ levels had differences in only 2 of the 5 years, 2000 and 2003, with no clear association with a specific fertilizer. Leaf tissue $\mathrm{S}$ levels were significantly different in 3 of the 4 years they were analyzed with no clear association with a specific fertilizer.

Changes to soil test recommendations. A typical program for producing onions from transplants would include a preplant incorporated application of $448 \mathrm{~kg} \cdot \mathrm{ha}^{-1}$ of $5 \mathrm{~N}-$ 4.4P-12.4K-9S fertilizer followed by 168 $\mathrm{kg} \cdot \mathrm{ha}^{-1}\left(\mathrm{NH}_{4}\right)_{2} \mathrm{H}_{2} \mathrm{PO}_{4}$ within 1 month of transplanting. This would be followed by two $336 \mathrm{~kg} \cdot \mathrm{ha}^{-1}$ applications of $6 \mathrm{~N}-5.2 \mathrm{P}-$ $14.9 \mathrm{~K}-4 \mathrm{~S}$ in January (2 weeks apart) and applications in mid-February and 1 Mar. of $224 \mathrm{~kg} \cdot \mathrm{ha}^{-1}$ of $\mathrm{Ca}\left(\mathrm{NO}_{3}\right)_{2}$. This program would result in $162 \mathrm{~N}-89 \mathrm{P}-156 \mathrm{~K}-67 \mathrm{~S}$ (Boyhan et al., 2001). Based on the results of this study, both $\mathrm{P}$ and $\mathrm{K}$ fertilizer could be reduced from this standard program without any loss in yield or quality. The site soil where these experiments were conducted, although typical for most of the onion-growing region, were somewhat heavier than some onion-growing soils, particularly in the southern parts of the region; therefore, 
changes to the soil test recommendations were conservative.

Our soil test recommendations for $\mathrm{P}$ and $\mathrm{K}$ is based on classifying south Georgia Coastal Plain soils into four classes of low, medium, high, and very high. Based on this study, the $\mathrm{P}$ and $\mathrm{K}$ recommendations have been cut approximately in half (Table 3 ). In addition, a new test level has been added called "overload" for extremely high levels of either $\mathrm{P}$ or $\mathrm{K}$, which triggers a $0 \mathrm{~kg} \cdot \mathrm{ha}^{-1}$ recommendation.

In conclusion, this study has identified that $\mathrm{P}$ and $\mathrm{K}$ were being overused in onion production and with this, a reduced range of recommendations from the University of Georgia's soil test laboratory should save growers money while still producing a good yield of quality onions.

\section{Literature Cited}

Abo-Zeid, M.I. and M.A. Farghali. 1996. Potassium fertilization and plant density effects on onion grown in different soils. Assiut J. Agr. Sci. 27:33-45.

Al-Moshileh, A.M.P. 2001. Effect of nitrogen, phosphorus and potassium fertilizers on onion productivity in central region of Saudi Arabia. Assiut J. Agr. Sci. 32:291-305.

Boyhan, G.E., D.M. Granberry, and W.T. Kelley. 2001. Onion Production Guide. Univ. of Georgia Bul. No. 1198.

Boyhan, G.E., A.C. Purvis, W.M. Randle, R.L. Torrance, M.J.I. Cook, G. Hardison, R.H. Blackley, H. Paradice, C.R. Hill, and J.T. Paulk. 2005. Harvest and postharvest quality of short-day onions in variety trials in Georgia, 2000-2003. HortTechnology 15:694-706.

Boyhan, G.E., R.L. Torrance, D.E. Curry, P.M. Lewis, D.O. Linton, and C.R. Hill. 2002. Evaluation of transplant fertility of short-day onions in Southeast Georgia. HortScience 37:651-655.

Coolong, T.W., D.A. Kopsell, D.E. Kopsell, and W.M. Randle. 2004. Nitrogen and sulfur influ- ence nutrient usage and accumulation in onion. J. Plant Nutr. 27:1667-1686.

Coolong, T.W. and W.M. Randle. 2003. Ammonium nitrate fertility levels influence flavour development in hydroponically grown 'Granex 33' onion. J. Sci. Food and Agr. 83:477482.

Gamiely, S., W.M. Randle, H.A. Mills, D.A Smittle, and G.I. Banna. 1991. Onion plant growth, bulb quality, and water uptake following ammonium and nitrate nutrition. HortScience 26:1061-1063.

Gomez, K.A. and A.A. Gomez. 1984. Statistical procedures for agricultural research. Wiley, N.Y.

Grandage, A. 1958. Orthogonal coefficients for unequal intervals. Biometrics 14:287-289.

Guo XiSheng, C.Y. Liu, and W.J. Wang. 1999. The effect of $\mathrm{K}$ fertilizer on the yield, qualities and nutrient uptake of onion. China Veg. 2:12-14.

Inal, A., X. Tarakc, and C. Oglu. 2001. Effects of nitrogen forms on growth, nitrate accumulation, membrane permeability, and nitrogen use efficiency of hydroponically grown bunch onion under boron deficiency and toxicity. J. Plant Nutr. 24:1521-1534.

Isaac, R.A. and W.C. Johnson, III 1985. Elemental analysis of plant tissue by plasma emission spectroscopy: Collaborative study. J. Assoc. Anal. Chemists 68:499-505.

Jha, A.K., N. Pal, and N. Singh. 2000. Phosphorus uptake and its utilization by onion varieties at different stages of growth. Indian J. Hort. 57: 347-350.

Mehlich, A. 1953. Determination of P, Ca, Mg, K, $\mathrm{Na}$, and $\mathrm{NH}_{4}$. North Carolina Soil Test Division (Mimeo 1953).

Randle, W.M. 2000. Increasing nitrogen concentration in hydroponic solutions affects onion flavor and bulb quality. J. Amer. Soc. Hort. Sci. $125: 254-259$

Randle, W.M. and M.L. Bussard. 1993. Streamlining onion pungency analyses. HortScience 28:60.

Rodríguez, S.N., N.C. Belmar, and P.A. Valenzuela. 1999. Effect of nitrogen, phosphorus and potas- sium rates, sources and forms upon onion (Allium cepa) bulb yield and quality. Efecto de dosis, fuentes y formas de aplicación de nitrogeno, fósforo y potasio en la producción y calidad de bulbos de cebolla (Allium cepa). Agricultura Técnica (Santiago) 59:122-132.

Sharma, R.P., N. Datt, and P.K. Sharma. 2003. Combined application of nitrogen, phosphorus, potassium and farmyard manure in onion (Allium cepa) under high hills, dry temperate conditions of north-western Himalayas. Indian J.Agr. Sci. 73:225-227.

Singh, A., S.P. Singh, and B.O. Singh. 2002. Effect of VAM and inorganic fertilizers on growth and yield of onion (Allium cepa L.). Veg. Sci. 29:40-42.

Singh, R.B. and S.B. Singh. 1999. Effect of nitrogen, phosphorus and potassium on growth and yield of rainy season onion (Allium cepa L.) raised from seedling. Veg. Sci. 26:93-94.

Singh, R.B. and S.B. Singh. 2000. Significance of nitrogen, phosphorus and potassium on onion (Allium cepa L.) raised from onion sets (bulblets). Veg. Sci. 27:88-89.

Singh, S.P. and A.B. Verma. 2001. Response of onion (Allium cepa) to potassium application. Indian J. Agr. 46:182-185.

Srinivasan, R., V. Shanmugam, A. Kamalakannan, and M. Surendran. 2002. Influence of fertilisers, host factors and storage conditions in relation to disease severity: A case study of black mould rot of onion. Acta Phytopathol. Entomol. Hung. 37:119-135.

State of Georgia 2005. Rules and regulations: Georgia Department of Agriculture/Food Division regulations/additional regulations applicable to Vidalia onions. 23 Mar. 2005 $<$ http://rules.sos.state.ga.us/cgi-bin/page.cgi?g= GEORGIA DEPARTMENT OF AGRICULT URE\%2FFOOD_DIVISION_REGULATIONS $\% 2 F A D D I T I O N A L$ REGULATIONS APPLI CABLE_TO_VIDALIA_ONIONS\%2Findex. html\&d=1>.

Stone, D.A. 2000. The effects of starter fertilizers on the growth and nitrogen use efficiency of onion and lettuce. Soil Use and Mgt. 16:42-48. 